\title{
STUDENTS METACOGNITIVE LEVEL ON SOLVING CHEMISTRY PROBLEMS
}

\author{
Ade Ira Nurjanah, Burhanudin Milama, Dila Fairusi \\ Syarif Hidayatullah State Islamic University of Jakarta, Indonesia \\ E-mail: burhanmilama@yahoo.com
}

Received: $14^{\text {th }}$ March 2016; Revised: $05^{\text {th }}$ April 2016; Accepted: $26^{\text {th }}$ June 2016

\begin{abstract}
Metakognitif adalah pengetahuan dan kesadaran tentang proses kognisi, atau pengetahuan tentang pikiran dan cara kerjanya. Dalam memecahkan masalah kimia, memerlukan keterlibatan metakognitif. Setiap siswa memiliki kemampuan metakognitif yang berbeda-beda. Penelitian ini bertujuan untuk mendeskripsikan level metakognitif siswa dalam memecahkan masalah pada materi kelarutan dan hasil kali kelarutan. Penelitian ini dilakukan di SMA Negeri di Tangerang Selatan dengan subjek penelitian sebanyak 104 siswa. Penelitian ini merupakan penelitian deskriptif kuantitatif sehingga datanya berupa hasil tes essai. Hasil tes essai tersebut dianalisis dan ditentukan level metakognitifnya berdasarkan indikator yang telah dibuat. Hasil yang diperoleh dari penelitian ini adalah sebanyak $14.42 \%$ siswa berada pada level metakognitif Aware Use, sebanyak $73.08 \%$ siswa berada pada level metakognitif Strategic Use dan sebanyak $12.50 \%$ siswa berada pada level metakognitif Relective Use. Siswa yang memiliki hasil belajar yang tinggi di dalam kelas berada pada level metakognitif Reflective Use. Siswa yang memiliki hasil belajar yang sedang di dalam kelas berada pada level metakognitif Strategic Use. Dan siswa yang memiliki hasil belajar yang rendah di dalam kelas berada pada level metakognitif Aware Use. Rata-rata level metakognitif siswa berada pada level metakognitif Strategic Use, karena rata-rata siswa dapat menggunakan dan menyadari strategi yang tepat dalam menyelesaikan masalah, tidak hanya mampu memahami masalah.
\end{abstract}

Keywords: pemecahan masalah; level metakognitif; hasil belajar.

\section{Abstrak}

Metacognitive is knowledge and understanding of the cognitive process or knowledge of mind, and it's work. Metacognitive is needed on solving the problem. Every student has different metacognitive abilities. This research is to describe students metacognitive level on solving chemicals molarity problem. This research was held in SMAN in South Tangerang, by 104 students as the subject research. This research is a quantitative descriptive by the essay results as the data. This result is analyzed, and the metacognitive level is stated based on the indicators. As the results of this research are $14.42 \%$ students are in Aware Use level, $73.08 \%$ in metacognitive Strategic Use level and $12.50 \%$ in metacognitive Reflective Use level. Metacognitive Reflective Use is the level for the high score students. Metacognitive Strategic Use is for middle score students. And metacognitive Aware Use for the low score students. Metacognitive Strategic Use level as the average. Most of the students can use and realized the right strategy on solving problems. Male students have a metacognitive level that is higher than for women.

Kata kunci: problem-solving; metacognitive level; learning achievement

How to Cite : Nurjanah, A., I. Milama, B. Fairusi, D. (2017). Students Metacognitive Level on Solving Chemistry Problems. TARBIYA: Journal of Education in Muslim Society, 4(1), 63-73. doi:10.15408/tjems.v4i1.5846.

Permalink/DOI: http://dx.doi.org/10.15408/tjems.v4i1.5846 


\section{Introduction}

Saving chemical problem is an important activity in learning chemistry. In solving the problem, there are several steps that must be taken. Bransford and Stain (1993) in Santrock (2008) claim that there are four steps in solving the problem, such as: Search and comprehend the problem; Arrange a good strategy to solve the problem; Explore solution; Re-think and redefine the problem and solution from time to time.

From those four steps in solving the problems, each student has different ability, some of them can search and understand the problem, some can also solve until the last step of re-think and re-define the problem and solution from time to time. The different ability existed because each student has the knowledge and different metacognitive skill.

John Flavell (1976) in Aurah, Casady, and McConel (2014), simply defines metacognitive as "thinking about thinking". In another way, Shetty (2014) declares that metacognitively comes from meta and cognitive. Meta means after or above and cognitive means to understand. So in terminology, metacognitive means cognitive about cognitive, knowledge about knowledge or think about what is being thought. According to Matlin in Amin and Sukestiyano (2015) metacognitive is knowledge and awareness about cognitive process or think of someone's thought.

Student activity in the use of awareness between cognitive and metacognitive functions in chemical problem solving becomes characteristic of different thinking patterns in each student. In solving problems, students will face problems that he has never encountered or has ever encountered. It can train students to use the knowledge and skills they have to solve problems so that their thinking ability increases.
Each student has different metacognitive knowledge and skills. There are students who have good metacognitive knowledge and skills and there are also students who have inadequate metacognitive knowledge and skills. Lack of knowledge and metacognitive skills of students will interfere with student learning and problemsolving. To improve metacognitive skills, there is a need for awareness that must be possessed by students in the process of thinking. However, each student has different abilities in response to a problem. Some students consciously pay attention to the problem given by resolving hierarchically, but there are also students who just carelessly reply when faced with the problem. This is because of the level of awareness or different metacognitive levels. According to Swartz \& Perkins (1998), metacognitive level consists of 4 levels of tacit use, Aware Use, Strategic Use and Reflective Use.

Lack of knowledge and metacognitive skills of students will disrupt the learning process and problem-solving. To improve metacognitive skills, it is a necessary awareness that must be possessed by students in the process of thinking. However, each student has different abilities in response to a problem. Some students consciously pay attention to the problem given by resolving hierarchically, but there are also students who just carelessly reply when faced with the problem. This is due to different levels of awareness or metacognitive levels. According to Swartz \& Perkins (1998), metacognitive level consists of 4 levels, namely tacit use, aware use, strategies use, and reflective use.

1. Tacit use is the use of thought without consciousness. The type of thinking associated with the decision without thinking of the decision. In this case, students apply strategies or skills without special awareness or through trial and error and originally answer in solving problems. 
2. Aware use is the use of conscious thought. The kind of thinking that relates to students' awareness of what and why students think. In this case, the students realize that he must use a problem-solving step by explaining why he chose to use the move

3. Strategic use is the use of strategic thinking. The kind of thinking that relates to the individual arrangement in his thinking process consciously by using specific strategies that can improve the accuracy of his thinking. In this case, students are aware and able to select specific strategies or skills to solve the problem.

4. Reflective use is the use of reflective thinking. The kind of thinking that relates to individual reflection in the thinking process before and after or even during the process takes into consideration the continuation and improvement of the thought result.

In this case, students realize and repair their errors in the process of problem-solving.

Because of differences in students' metacognitive level in solving problems, it is necessary to analyze the metacognitive level of the students in solving problems. The problem taken in this research is solubility and result of solubility. Solubility and result of solubility are selected because in solving that problems require complex thinking skills and complex problem solving requiring metacognitive engagement. Also, solubility and result of solubility are calculated materials and solving the problem needs sequential problem-solving steps. Analysis of the students' metacognitive level needs to be done so that teachers can choose and determine teaching patterns and learning models are better.

\section{Method}

The study is descriptive quantitative. This study aimed to describe the students' metacognitive level in solving problems on the topic of solubility and solubility product.

Data collection techniques used in this study is a test. The test was a written test in the form of essay, where all students of class 2 of XI natural sciences follow the daily test of solubility material and result of solubility. Before the test began, students were divided into three groups that are high, medium, and low group. The selection of the group member was depended on the students' learning results in the classroom, $25 \%$ of the students have high-performance results, $50 \%$ of the students have medium performance results, and $25 \%$ of the students have low performance result (Indriati et al. 2012)

After grouping and doing metacognitive level tests on solubility and result of solubility, students were categorized again into three groups: high, medium, and low. This categorization is based on the results of the students' metacognitive level tests on solubility and result of solubility. Students are in a high group if the metacognitive test results are greater than or equal to the average number of student test results and standard deviation. Students are in a medium group if the test results obtained are among the average number of student test results minus the standard deviation and the average number of student test results plus the standard deviation. Students are in a low group if the metacognitive level test results are less than the average number of student test results minus standard deviation.

After being grouped based on metacognitive level test results, the written test results were analyzed based on the problem-solving step and determined the metacognitive level of each item 
based on the metacognitive level criteria adopted from Theresia Laurent (2010). After that, the students' metacognitive level was determined based on the dominant metacognitive level in each student. The next procedure is concluding the students' metacognitive level based on the metacognitive level that is dominant on each student. The differences of students' metacognitive level based on gender are also determined in this study.

\section{Results and Discussion}

The results of research that can be in the form of metacognitive level test results of students who have been given material about solubility and solubility results. The following is presented data on the acquisition of metacognitive level test results of students in solving problems on solubility and solubility

Tabel 1. The result of students' metacognitive test for class of XI IPA (Natural

Sciences) at State High School in South Tangerang

\begin{tabular}{llll}
\hline $\begin{array}{l}\text { Numbe } \\
\mathbf{r}\end{array}$ & $\begin{array}{l}\text { Level of } \\
\text { Metacognitive }\end{array}$ & $\begin{array}{l}\text { the } \\
\text { number of } \\
\text { students }\end{array}$ & $\begin{array}{l}\text { percentag } \\
\mathbf{e}\end{array}$ \\
\hline $\mathbf{1}$ & Tacit Use & 0 & 0 \\
$\mathbf{2}$ & Aware Use & 15 & 14.42 \\
$\mathbf{3}$ & Strategic Use & 76 & 73.08 \\
$\mathbf{4}$ & Reflective Use & 13 & 12.50 \\
Total & & 104 & 100 \\
\hline
\end{tabular}

Based on table 1 it can be seen that as many as 15 or $14.41 \%$ of students have metacognitive aware use level, 76 or $73.08 \%$ of students have metacognitive strategic use level, and 13 or $12.50 \%$ of students have reflective use metacognitive level. To know more clearly, the following data presented metacognitive level test results of students by group and gender.

\section{Metacognitive level test results of high group students}

High-ability students in the class (high group students) have good results as well when metacognitive level tests are conducted on solubility and solubility tests. As many as 13 or $50 \%$ of students. The high group students stand at Strategic Use Meta Cognitive Stage and around 13 or $50 \%$ high group students are standing at Reflective Use Meta Cognitive Stage.

From six questions that have been tested, for each question, every member of high group students has occupied in a different level of Meta cognitive stage. In some questions, some upper students groups have stood at Reflective Use Meta Cognitive stage and the others have stood at Strategic use Meta Cognitive Stage. High group students can write the data which is being known and being asked in the question. These things show us that high group students can understand the problem. Besides that, high group students can plan the steps of problemsolving, solve their problem correctly, and in some questions, they evaluated during solving the problem, as well as they can give the final result.

In this research, the high group students or the students which has a high score and learning result in the class or can be categorized as "high" when they were being tested in resolving the problem of solubility and solubility product. This case is in line with Al-Zoubi and Nurmaliah (2009) research that the student who have high score in learning process, was also in high stage in meta cognitive. Every member of High group students has stood at the same level which is Strategic Use and Reflective Use. This case also in line with what Sophiningtyas and Sugiarto(2013), the students in high group students have stood at Reflective Use Meta Cognitive Stage. In another research, the research of Mahromah and Manoy (2013) assume that the student who had the high ability is categorized in Strategic Use Meta Cognitive stage. 
In some cases, high group students have stood at Reflective Use Meta Cognitive stage. Meanwhile, in some cases, the others had stood at Strategic Use Meta Cognitive stage. When high group students have stood at Reflective Use Meta Cognitive stage can reflecting their mind, not only can figuring and understanding the problem correctly, but also can make decision consciously in resolving the problem and considering the final result. When metacognitive strategic use High group students can understand the problem because it can clarify clearly, able to find out the ways used to solve problems and not to evaluate the results of his thinking.

The following data The figure 1 presented written test results representative of high student group (student 1 ) on problem number 1 with a problem: "in 4 litters of water at $25^{\circ} \mathrm{C}$ can dissolve as much as possible 13.28-gram $\mathrm{Ag}_{2} \mathrm{CrO}_{4}$. Determine the solubility of $\mathrm{Ag}_{2} \mathrm{CrO}_{4}$. $(\mathrm{Ar} \mathrm{O}=16 ; \mathrm{Cr}=52 ; \mathrm{Ag}=108) "$ In this question, high group students (students 1 ) are at the reflective use metacognitive level.

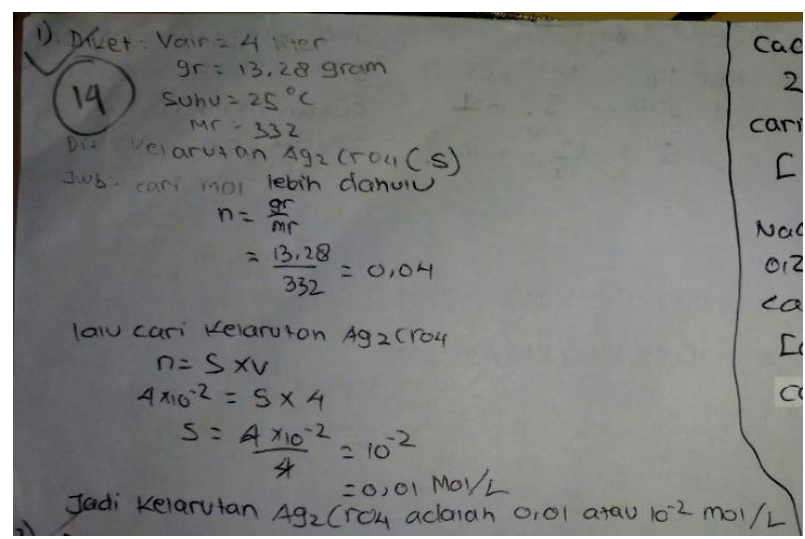

Figure 1. Presented Written Test Results

Representative of High Student Group

Based on the results of the written test (student 1) on the number 1 note the existence of writing "diket" and "dit", the meaning of "diket" is "Diketahui" and "dit" is "ditanya". So by writing "diket and ditanya", (student 1) has written data to solve the problem, that is water volume, temperature, massaAg $\mathrm{CrO}_{4}$ and $\mathrm{Mr}$ $\mathrm{Ag}_{2} \mathrm{CrO}_{4}$. Student 1 also writes asked data, is solubility or written with the symbol S. It shows that student 1 has been able to search and understand the problem correctly in its metacognitive activity.

On picture 4.1 is also written "jwb" which means "jawab", in this section "student 1 " write a problem-solving strategy in the form of looking for $\mathrm{molAg}_{2} \mathrm{CrO}_{4}$ first then look for solubility $\mathrm{Ag}_{2} \mathrm{CrO}_{4} . \mathrm{MolAg}_{2} \mathrm{CrO}_{4}$ produced correctly, and the agglutination answer is also true. The process of getting the Mol and the solubility is also true. Based on the results of the above analysis "student 1" perform the process of problemsolving and monitoring activities in Metacognitive activity which includes writing down the problem-solving procedure accordingly, the procedures used are correct, and the results are also true

In figure 4.1, student 1 writes a word "jadi” in the last part of their answer. The writing of the word "jadi" shows that the student 1 conducted an evaluation process in solving problems and an evaluation activity on their metacognitive activity.

Based on the written data, it is obtained that student 1 can understand the problem correctly, plan problem-solving steps and solve the problem correctly, and his final result. The analysis result and compatibility with indicator explain that student 1 is in the metacognitive level of Reflective Use.

On another question, high group students (student 1) have different metacognitive level, as in question number 6 . In the question, student 1 is in the metacognitive level of Strategy Use.

Based on the result of the written test from a representative of the high group students above, it is showed that the high group students could be in metacognitive Strategy Use and 
Reflective Use Level. Because of the metacognitive level that is dominant on the high group students (student 1) is Reflective Use, so the high group students (student 1) is in Reflective Use Level. This is in line with the research which was conducted by Sophiningtyas and Sugiarto (2013), the students in the high group are in metacognitive Reflective Use Level. The high group students are in Reflective Use Level because they can reflect back on their thinking. They are not only able to discover the problem and to plain a good problem-solving strategy but also they can take decisions consciously in problem-solving and considering the result. (Safitri \& Saleh, 2015)

The Result of Metacognitive level of middle group students

Based on the result of the research, it was found that student who has the average ability in the class (the middle group students) has a pretty good result when metacognitive level test is done on the solubility and solubility product. As many as 52 or $100 \%$ of the middle students' group are in metacognitive Strategy Use Level.

Middle group students have a metacognitive level of strategic Use. From 6 questions given, every student has different metacognitive level from each question. In some questions, students are in Reflective Use Level, and some other questions are in Strategic Use and Aware Use Level. However, metacognitive level on middle group students is dominated by Strategic Use.

When middle group students are in metacognitive Reflective Use level, they can reflect back their thinking, they are not only able to discover, to understand the problem, and to plan the strategies to fix the problem but also they can take a decision consciously in problemsolving and considering to get the result. When they are in the metacognitive level of Strategic Use, they can understand the problem correctly, comprehend the chemistry concepts related to the given problem, able to recognize concept's error (formula) and how to calculate; however, they cannot fix it and evaluate it through their result thought.

When they are in metacognitive aware use, they can understand the problem well and comprehend the chemistry concepts which underlying the problems. However, middle group students have difficulty and perplexity in establishing the formula and how to calculate that will be used, so that they cannot continue what they did. According to Mahromah and Manoy (2013) "students with metacognitive Aware Use have metacognitive activities, such students can understand the problem because they can reveal it clearly, able to realize the concept's error (formula) and how to calculate, but cannot fix it evaluate it through their result thought."

The written test result of the representative of middle group students (students 15) on question 2 that " $100 \mathrm{ml}$ of the saturated solvent of magnesium fluoride $\left(\mathrm{MgF}_{2}\right)$ were evaporated on $18^{\circ} \mathrm{C}$, and the result taken is $7,6 \mathrm{mg}$ of solid $\mathrm{MgF}_{2}$. What is $\mathrm{K}_{\mathrm{sp}}$ of $\mathrm{MgF}_{2}$ at $18^{\circ} \mathrm{C}$ ? $(\mathrm{Ar} \mathrm{Mg}=$ $24 ; F=19)$ ", is shown in figure 4.2. With this question, middle group students are in metacognitive Strategic Use.

Based on the result of student 15 written test on number 2 , it is seen that the student has been able to find and comprehend the problem correctly in their metacognitive activities. This can be seen from the writing of Dik and Dit. Student 15 have written data to solve the problem that is $\mathrm{MgF}$ volume, the mass of $\mathrm{MgF}_{2}$, and $\mathrm{Mr} . \mathrm{MgF}_{2}$. Student 15 also writes the data asked, that is the results of $\mathrm{MgF}_{2}$ solubility or written with the symbol Ksp. 


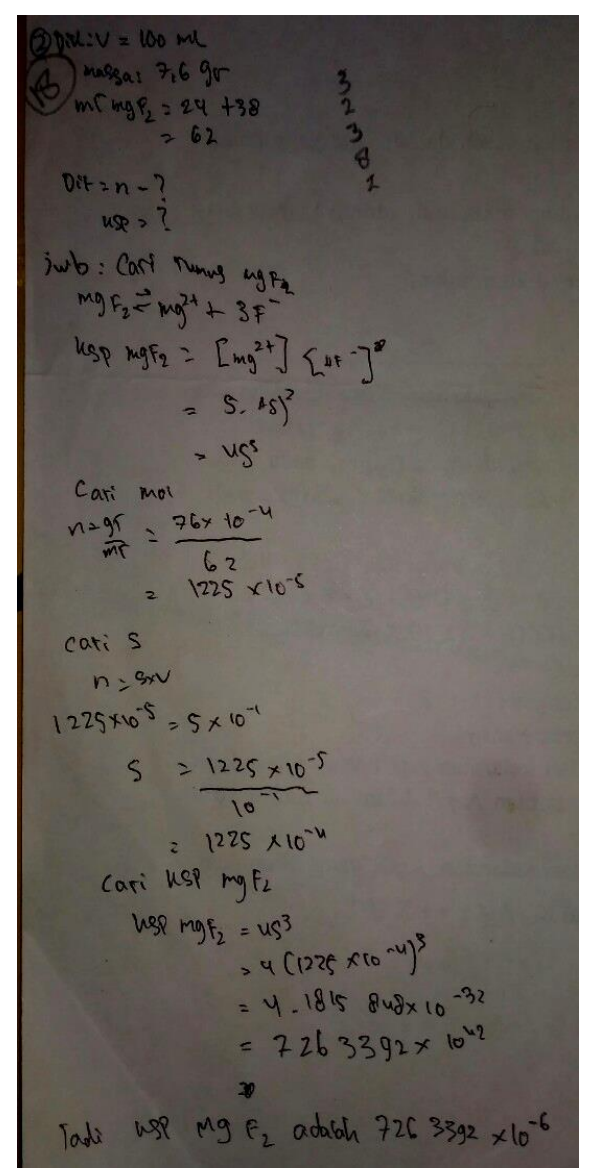

Figure 2.

In Figure 2 there is also writing jwb which means answer, in this section student 15 write a problem-solving strategy in the form of finding $\mathrm{KspMgF}_{2}$ formula first then look for $\mathrm{MgF}_{2}$ mol,the solubility of $\mathrm{MgF} 1$, then look for the $\mathrm{Ksp} \quad \mathrm{ofMgF}_{2}, \mathrm{KspMgF}$ formula that produced right, the answer of $\mathrm{Mgf}_{2}$ molis generated less precisely, the resulting $\mathrm{MgF}_{2}$ solubility and the resulting $\mathrm{KspMgF}_{2}$ are also less precise. The process of getting the Ksp formula is correct, the process of getting the mole, solubility, and $\mathrm{KspMgF}_{2}$ is also true but when doing calculations, the resulting answer is less precise. Based on the above analysis, student 15 performs the solution process about solving the problem but lacks conducting monitoring activity in metacognitive activity which includes writing down the problem-solving procedure precisely, the procedure used is correct but the result obtained is less precise.
In Figure 2 the student 15 writes the finished word at the end of the answer. This indicates that the student 15 performs an evaluation process in solving the problem and activity evaluation on its metacognitive activity. But in the process of evaluation, the student is less careful, so it is wrong to conclude.

Based on the written data obtained, student 15 can find and comprehend the problem correctly, plan the problem-solving steps, solve the problem with inappropriate results, less evaluate during the process of solving the problem and the final result. Based on analysis result and conformity with an indicator of student 15 is at Strategic Use metacognitive level.

On the other question, student 15 is at the Reflective Use and Aware Use metacognitive level. As in the question number 1, the middle group students (student 15) is at the Reflective Use metacognitive level and in the question number 4 is at the Aware Use metacognitive level.

The results of the written test of the middle group students (student 15) above show that in some questions the middle group students are at the Reflective Use metacognitive level and on some other questions are at Strategic Use and Aware Use metacognitive level. Because the dominant metacognitive level in the middle group is Strategic Use, therefore the metacognitive level of middle group students is Strategic Use. This is in line with research conducted by Sophinigtyas and Sugiarto (2013), students with moderate scores are at the Strategic Use metacognitive level. The middle group students are at the Strategic Use metacognitive level because they use and realize the right strategy in solving the problem, not only be able to understand the problem. It is in line with the study done by Sholih and Sugiarto (2014) that 
the students of the middle group are in the metacognitive level of Strategic Use.

\section{Metacognitive Level Test Results of Low Group Students}

Based on the results of the study, it is found that students who have low ability in the class have variety results when metacognitive level test is conducted on solubility material and solubility product.

Eleven Students or as many as $42 \%$ of lowgrade students stayed at the "Strategic Use" metacognitive level, and 15 or $58 \%$ of low group students are at the "Aware Use" metacognitive level. Most of the metacognitive level test result in the low group were at the "Aware Use" metacognitive level.

Low group students are at the "Aware Use" metacognitive level where students can understand the problem but could not write the appropriate procedures and did not do the evaluation. In a research conducted by Safitri and Saleh (2015) students who were at the lowgrade level can be classified at Aware Use metacognitive level and could also be classified at the level of Tacit Use. In this study, no students are at the metacognitive level of Tacit Use, because all students were able to search and understand the problem correctly. According to Safitri and Saleh (2015) students were at the metacognitive level of Tacit Use if: students are less able to understand the problem well, students are less able to plan a problem-solving strategy well; The less able students are aware of the concept and the way the count is well used, And students are less able to conduct a good evaluation.

Of the six questions given, low group students could only do four out of six questions given to them. These students actually could understand the questions but could not finish them within the time limit. This suggests that low-grade students are less able to think fast and thus need more time to solve the problems

Of the six questions given, each student has different metacognitive level. Based on some questions, some low-grade students were at the "aware use" metacognitive level, and on the other hand, some low-grade students were at the "strategic use" metalogical level. However, the "aware use" metacognitive level is the dominant metacognitive level of the low-grade students. Staying at the metacognitive level Strategic Use, low-grade students were able to understand the problem correctly, able to write problem solving strategies and solved problems correctly, mastered the chemical concepts related to the given problem, were also able to realize concept errors (formulas) and the way to calculate but could not Fix it nor evaluate its results.

Classified at "Aware Use" metacognitive level, low-grade students were able to understand the problem well, understood the underlying chemical concepts of the problem, but they faced several difficulties and confusion when determining the formula and calculating. These conditions have made the low group students did not finish their work.

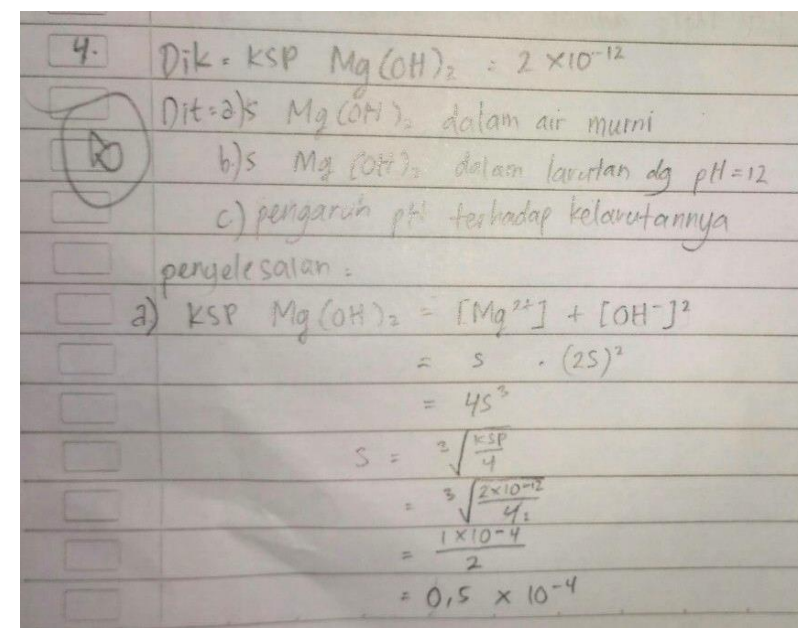

Figure 3. Test Results of Low Group Student Representation. Problem number 2 
Figure 3 showed written test results of a low group student representation (student 30) on question number 2 with " $100 \mathrm{~mL}$ saturated solution of magnesium fluoride $(\mathrm{MgF} 2)$ on 180 'C was evaporated, and $7.6 \mathrm{mg} \mathrm{MgF2}$ solid was obtained. How much is $\mathrm{Ksp} \mathrm{MgF} 2$ at 180 'C? $(\mathrm{Ar} \mathrm{Mg}=24 ; \mathrm{F}=19)$ ". In this case, low group students (students 30) were at the metacognitive Aware Use level.

Based on the result of student 30 on question 2, it could be seen that the student 30 wrote down the data that is known (Diketahui) and asked (Ditanyakan). This indicated that the student 30 has been able to search and understand the problem correctly in his metacognitive activity.

What the formulation resulted is correct, but the solubility is not quite correct. Student 30 can not overcome problem number two well. Student number 30 can not answer the question about solubility $\mathrm{Mg}(\mathrm{OH})_{2}$, in solvent $\mathrm{pH} \mathrm{12}$, dan checking how the effect of $\mathrm{PH}$ on the solubility. Based on analysis result above, student number 30 can not do observation activity in metacognitive activity which includes, writing appropriate procedure of problem-solving, procedure which is used is correct but (s)he can not overcome it until the end, so the result is not quite appropriate.

On Figure 3, we can see that student number 30 can not overcome his/her problem clearly, so $s($ he) can not give a conclusion at the end of the answer. It shows that student 30 does evaluation process to overcome the problem and evaluation activity in his/her metacognitive activity.

Based written data, we can get the fact that student 30 can understand the problem correctly, does not write steps of problem-solving plan, and can not overcome problem correctly, and the final result. Based on analysis result and the compatibility with an indicator, the metacognitive level of student 30 is Aware Use.

In the other case, low group student (student 30) is in the metacognitive level of Strategic Use. As seen at question number 3, low group student is in the metacognitive level of Strategic Use.

Based on a written test of representation of low group student (student 30) above shows that on some question, they are in the metacognitive level of Strategic Use and some question, they are in Aware use. Because the metacognitive level of Aware Use is dominant at the low group, so their level is Aware Use. It is in line with the research conducted by Sophiningtyas and Sugiarto (2013), a student with a low score is in the metacognitive level of Aware Use. Low group student is in the metacognitive level of Aware Use because they realize what they do in problem-solving, know what they know, and realize that they have to use something.

Step to solve the problem by explaining why she/he chooses that step to use. However, a student who in Aware Use metacognitive level can not explain why she/he uses that step or gives an unclear explanation (Rahayu \& Azizah, 2012).

Metacognitive Level Result of Male and Female Students

Table 2. Metacognitive Level Result of Males and Females Students

\begin{tabular}{lll}
\hline Metacognitive & Gender & \\
\cline { 2 - 3 } Level & Male & Female \\
Tacit Use & 0 & 0 \\
Aware Use & 6 & 8 \\
Strategic Use & 29 & 48 \\
Reflective Use & 12 & 1 \\
Total & 47 & 57 \\
\hline
\end{tabular}

According to Table 2, it can be seen that male students have a higher metacognitive level compared to female students. About 12 male students place at Reflective Use metacognitive 
level and only one female student place at Reflective Use metacognitive level. It complies with the research which is conducted by AlAkhyat (2012) that there are significance statistic differences between male and female students ability in metacognitive and creative thinking, and also high thinking metacognitive from students' perspective. Male students have better metacognitive ability compared to female students.

\section{Conclusion}

Based on data analysis result and discussion, it can be concluded that about $14.42 \%$ students place at Aware Use metacognitive level, about $73.08 \%$ students place at Strategic Use metacognitive level and about $12.50 \%$ students place at Reflective Use metacognitive. A student who has a high study result in the classroom (high group) has high result of a metacognitive test level. A student who has high study result in the classroom place at Reflective Use Metacognitive level. A student who has average study result in the classroom (average group) place at Strategic Use metacognitive level. A student who has low study result in the classroom (low-class place at the level.

\section{References}

Al-Khayat, M. M. (2012). The Level of Creative Thinking and Metacognitive Thinking Skill of Intermediate

Al-Zoubi, S. M. (2013). The Level of Metacognitive Thinking Among Special Education Students. Prime Research on Education (PRE), 3(2), 437-441.

Amin, I \&Sukestiyarno. (2015). Analysis Metacognitive Skills On Learning Mathematics In High School.
International Journal of Education and Research, 3(3), 213-222.

Aurah, C. M., Casady, J.C., MCConnell, T. J. (2014). Genetics Problem Solving In High School Testing In Kenya: Effects Of Metacognitive Prompting During Testing.Electronic Journal of Science Education, 18(8), 1-26.

Indriati, M., \& Syafrianti, T. (2012). Penerapan Model Pembelajaran Kooperatif Teknik Think Pair Square (TPS) untuk Meningkatkan Hasil Belajar Matematika Siswa Kelas VIII, SMP Islam YLPI Pekan Baru. Prosiding Seminar Nasional Matematika dan Pendidikan Matematika FMIPA UNY. 582-590. ISBN: 978-97916353-8-7.

Laurens, T. (2010).Penjenjangan Metakognisi Siswa yang Valid dan Reliabilitas. Jurnal Pendidikan dan Pembelajaran, 17(2), 201213.

Mahromah, L. A., \& Manoy, J. T. (2013). Identifikasi Tingkat Metakognisi Peserta didik dalamMemecahkan Masalah Matematika Berdasarkan Perbedaan Skor Matematika. MATHEdunesa, 2(1), 1-8.

Nurmaliah, C. (2009). Analisis Keterampilan Metakognisi Siswa SMP Negeri di Kota Malang Berdasarkan Kemampuan Awal, Tingkat Kelas, dan Jenis Kelamin. Jurnal Biologi Edukasi, 1(2), 18-21.

Rahayu, P., \& Azizah, U. (2012).Students' Metacognition Level Through Of Implementation Of Problem Based LearningWith Metacognitive Strategies At Sman 1 Manyar. Unesa Journal of Chemical Education, 1(1), 164-173.

Satrock, J. W. (2008). Psikologi pendidikan. Jakarta: Kencana. 
Shetty, G.(2014). A Study of the Metacognition Levels of Student Teachers On The Basis Of Their Learning Styles. IOSR Journal of Research \& Method in Education (IOSRJRME),4(1), 43-51.

Safitri, K. R., \& Saleh, M. (2015).Analisis Pemecahan Masalah Matematika Menggunakan Metakognisi. Prosiding Seminar Nasional Matematika dan Pendidikan Matematika UMS, 470485.ISBN : 978.602.361.002.0.
Sophianingtyas, F., \& Sugiarto, B. (2013).Identifikasi Level Metakognitif Siswa dalam Memecahkan Masalah Materi Perhitungan Kimia.UNESA Journal of Chemical Education.2(1), 21-27.

Swartz, R \& Chang, A. (1998). Intructional Strategies for Thinking Classroom. Singapura: National Institute of Education. 